\title{
ACTIVATED CARBON AMENDMENT TO REMEDIATE CONTAMINATED SEDIMENTS AND SOILS: A REVIEW
}

\author{
I. HILBER \\ T.D. BUCHELI*
}

\author{
Agroscope Reckenholz-Tänikon Research Station ART \\ Reckenholzstr. 191, CH-8046 Zürich, Switzerland
}

*to whom all correspondence should be addressed:

\begin{abstract}
Activated carbon (AC) amendment for reduction of contaminant exposure in polluted soils and sediments has recently emerged as a promising remediation technique. Here, we provide a short overview of the state-of-the-art in activated carbon (AC) amendment to such sites. Most studies not only in sediments but also in soils were carried out in the laboratory and only a few in the field. Consequently, practical experience at the field scale is largely lacking, and feasible engineering approaches for AC amendment still need to be developed, especially for soils. The effectiveness of the AC treatment was evaluated by comparison of pollutant concentration reduction in the various endpoints with those in the unamended control matrix. Endpoints in use comprise pollutant concentrations in benthic organisms, depletive and non-depletive methods to quantify pollutant exposures, as well as various toxicity endpoints of plants. Half of the studies in soils and $68 \%$ of the studies in sediments showed reduced pollutant availabilities of $>50 \%$ after AC amendment. Observed low reductions $(<50 \%)$ might be due to low exposure time, insufficient equilibrium time for coke breeze, biochar, and granulated AC, overload of AC material, different uptake pathways of benthic organisms, and pollutant reductions outside the dynamic range of toxicity endpoints. Further research is needed to establish ideal AC amendment conditions to sediments and soils, leading to significantly reduced pollutant bioavailability.
\end{abstract}

KEYWORDS: black carbon, remediation, soils, sediments, benthic organisms, biomimetics, plants, amendment techniques, reduction.

\section{INTRODUCTION}

Our society faces large polluted areas, such as soils from land fills or harbour sediments from industrial sites. The reuse of these field soils is increasingly demanded due to urban sprawl. Similarly, polluted sediments pose risks to humans in urban (recreational) areas and to the environment in general. Remediation techniques are therefore urgently needed. A whole series of approaches are discussed in the literature (Castelo-Grande et al., 2010), ranging from capping (Lowry et al., 2006; Murphy et al., 2006), locking (Ying et al., 2005; Bartelt-Hunt et al., 2006), over phytoremediation, in situ chemical treatment, to dredging and excavation. Among all these, activated carbon (AC) amendment has proven to be a promising option for the reclamation of such sites not only for organic but also for inorganic pollutants (Bes and Mench, 2008).

Activated carbon successfully reduces the bioavailability of organic contaminants due to its strong sorption properties (Bucheli and Gustafsson, 2000). Additionally, AC amendment may be preferred over other remediation possibilities for several reasons. First, as an in situ technique, it is more cost effective compared to off site remediation and environmental friendly in as much as it does not move contamination problems from one place to another. Second, if done properly, it does not release new amounts of pollutants, as it may take place e.g. while dredging or digging. Third, it is often more effective than, e.g., cleaning with surfactants or other chemicals (ex or in situ) or phytoremediation. 
The plants can only withdraw a few percent of the pollutant and have a long growth period to develop a reasonable plant biomass (White, 2009).

In spite of these advantages, there are also some concerns related to AC amendment. Major issues are the costs and availabilities of sufficient amounts of suitable forms of $A C$, necessary to treat extended areas of pollution. Therefore, researchers started to use alternative carbon material like e.g. biochar (Yu et al., 2009), coke breeze (Zimmerman et al., 2004; Millward et al., 2005), waste AC (Guo et al., 1991), fly ash (Burgess et al., 2009), and many more. Further drawbacks and side effects of AC amendment, such as the stability of the AC material, physical alteration of the matrices, direct or indirect harmful effects on, and nutrient availability to organisms will be discussed in "Factors potentially reducing the efficiency of $A C$ amendment and other side effects" section. Overall and in any case, environmental engineers have to balance the positive aspects of AC amendment against potentially adverse, and consider this technique in concert with others to optimize the reclamation strategy at individual sites.

In this review, we focus on processed and condensed carbons and do not discuss the vast field of organic waste amendment like, e.g., sewage sludge, manure, or shredded plant material mainly used as fertilizers or for soil improvement. Another topic not discussed in this paper is the modelling aspect associated with the $A C$ amendment and the water purification. Further, we restrict the discussion to AC amendment to sites polluted with organic chemicals. The objective of this review is to (i) describe the state-of-the-art in AC amendment methodology in soils and sediments, (ii) to indicate the effectiveness of the treatment expressed as the percentage of the concentration's and plant's toxicity reduction in the endpoint compared to the unamended matrix, and (iii) to identify research gaps and efficiency questions of $A C$ amendment.

\section{OVERVIEW OF EVALUATED STUDIES}

Tables 1 and 2 contain a systematic list of the literature evaluated in this review, whereas Table 3 provides a condensed overview. A range of amendment studies were carried out with sediments (Table 1) and soils (Table 2) in the laboratory and/or in the field. Most studies used powdered AC (PAC) in a wide concentration range, and were overwhelmingly conducted in the laboratory (Table 3). Most of the work compiled here was conducted in the last decade, but three studies in soils were done earlier. This temporal development goes hand in hand with a shift in the application purpose, moving from early agricultural applications to later trials of $A C$ amendment to mitigate sediment contamination. Usually, the results are expressed in relevant endpoints which serve as quality control measures of the reclamation technique, such as the freely dissolved concentration, depletive methods mimicking bioaccessibility, biota to sediment/soil accumulation factors (BSAF), and bioaccumulation factors (BAF) of the organic contaminants. Below, these endpoints are compiled from the available studies to generate a condensed view of the overall $A C$ amendment efficiency.

\section{METHODOLOGICAL ASPECTS OF AC AMENDMENT}

We consider amendment techniques as one of the key factors influencing the efficiency of pollutant sequestration to the AC. On the one hand, the mixing should lead to a homogenous distribution of the $A C$ in the matrices of concern. On the other hand, this activity should be minimally invasive and avoid a (temporal) increase of pollutant exposure to the system. Sediments are not as easily accessible as soils which complicates the reclamation process in the field. Conversely, sediments may be easier to homogenize than soils, due to their water-saturated nature. The work of Cho et al., (2007) describes different amendment techniques in the field, such as mixing the AC slurry into the mud of San Francisco Bay with a rotovator, or injecting it with an injector. In the laboratory, Sun and Ghosh (2007) tested different addition modes of granulated AC (GAC) to sediments, such as mechanical mixing for two minutes (simulating the mixing in the field), and one month and surfacial coverage. For homogenization, AC amended sediment samples were placed on rollers (Millward et al., 2005; Zimmerman et al., 2005; Sun and Ghosh, 2008; Janssen et al., 2010), on end-over-end shakers (Cornelissen et al., 2006b; Brandli et al., 2009), or on other apparatuses. Quite often however, researchers did not bother to describe in detail how they amended the AC material to sediments. 
Table 1. AC amendment studies conducted in sediments

\begin{tabular}{|c|c|c|c|c|c|c|c|c|c|c|c|}
\hline Endpoint & $\begin{array}{l}\text { Study } \\
\text { type }\end{array}$ & Pollutant & $\begin{array}{l}\text { Sediment } \\
\text { conc. }\end{array}$ & Reduction & $\begin{array}{l}\text { Exposure } \\
\text { time }\end{array}$ & AC conc. & $\begin{array}{l}\text { Surface } \\
\text { area }\end{array}$ & Particle size & Trade name & AC-type & Reference \\
\hline & & & {$\left[\mathrm{mg} \mathrm{kg}^{-1}\right]$} & {$[\%]$} & [days] & [\%] & {$\left[\mathrm{m}^{2} \mathrm{~g}^{-1}\right]$} & {$[\mathrm{mm}]$} & & & \\
\hline Aqc & Lab & BT & $0.4-4.3$ & & 28 & 2 & 1300 & $0.015-0.15$ & $\begin{array}{l}\text { Norit SAE } \\
\text { Super }\end{array}$ & PAC & Brandli et al. (2009) \\
\hline $\mathrm{Aqc}$ & Lab & BT & $0.4-4.3$ & $\begin{array}{c}36.4- \\
89.5\end{array}$ & 28 & 2 & $1050-1200$ & $0.43-1.7$ & $\begin{array}{l}\text { Aquacarb } \\
208\end{array}$ & GAC & Brandli et al. (2009) \\
\hline Bo & Lab & PCB & 9.9 & 0.0 & 28 & 3.4 & 1000 & $\begin{array}{l}0.063-0.105 \\
0.105-0.25\end{array}$ & - & $\begin{array}{l}\text { Coke } \\
\text { breeze }\end{array}$ & Millward et al. (2005) \\
\hline Aqc, biom & Lab & $\begin{array}{l}\text { PCB, } \\
\mathrm{PAH}\end{array}$ & $9.9,8$ & $\begin{array}{r}-0.5- \\
64.7 \\
\end{array}$ & $28-180$ & $3.4,8.5$ & 3 & $\begin{array}{c}0.105-0.25 \\
0.063-0.105 \\
\end{array}$ & - & $\begin{array}{l}\text { Coke } \\
\text { breeze }\end{array}$ & $\begin{array}{l}\text { Zimmerman et al. } \\
(2004)\end{array}$ \\
\hline Bo & Lab & $\mathrm{PAH}$ & 1438.0 & $\begin{array}{r}15.0- \\
100.0\end{array}$ & 7 & $5,10,20$ & $\begin{array}{l}15.2,17,7 \\
35.3 \\
36.3 \\
37.3\end{array}$ & n.a. & - & Fly ash & Burgess et al. (2009) \\
\hline Bo & Lab & $\mathrm{PHE}$ & n.a. & 31.0 & n.a. & 3.5 & n.a. & 9.33 & - & Fly ash & Voparil et al. (2004) \\
\hline Aqc, biom & Lab & DDT & $\begin{array}{l}0.1- \\
252.0\end{array}$ & $\begin{array}{c}80.0- \\
81.0\end{array}$ & Equil & 3.2 & 935 & $0.074-0.177$ & TOG® & Unspecified & $\begin{array}{l}\text { Tomaszewski et al. } \\
(2007)\end{array}$ \\
\hline Aqc, biom & Lab & DDT & $\begin{array}{l}0.1- \\
252.0 \\
\end{array}$ & $\begin{array}{c}72.0- \\
73.3 \\
\end{array}$ & Equil & 3.2 & 935 & $0.074-0.297$ & TOG® & Unspecified & $\begin{array}{l}\text { Tomaszewski et al. } \\
(2007)\end{array}$ \\
\hline Aqc, biom & Lab & DDT & $\begin{array}{l}0.1- \\
252.0 \\
\end{array}$ & $\begin{array}{c}64.4- \\
67.0 \\
\end{array}$ & Equil & 3.2 & 1100 & $0.074-0.177$ & $\begin{array}{l}\text { Fitrasorb® } \\
400\end{array}$ & Unspecified & $\begin{array}{l}\text { Tomaszewski et al. } \\
(2007)\end{array}$ \\
\hline Aqc, biom & Lab & DDT & $\begin{array}{l}0.1- \\
252.0\end{array}$ & $\begin{array}{c}13.0- \\
13.3 \\
\end{array}$ & Equil & 3.2 & 1100 & $0.5-1$ & $\begin{array}{l}\text { Fitrasorb } \AA \\
400\end{array}$ & Unspecified & $\begin{array}{l}\text { Tomaszewski et al. } \\
(2007)\end{array}$ \\
\hline $\begin{array}{l}\text { Aqc, biom, } \\
\text { bo }\end{array}$ & Lab & DDT & $\begin{array}{l}0.1- \\
252.0\end{array}$ & $\begin{array}{c}22.2- \\
94.6\end{array}$ & $\begin{array}{l}\text { Equil, } \\
22-28\end{array}$ & 3.2 & 900 & $\begin{array}{c}0.595-2.38 \\
0.074-0.177\end{array}$ & $\begin{array}{l}\text { Aquacarb } \mathbb{} \\
830\end{array}$ & Unspecified & $\begin{array}{l}\text { Tomaszewski et al. } \\
(2007 ; 2008)\end{array}$ \\
\hline $\begin{array}{l}\text { Aqc, biom, } \\
\text { bo }\end{array}$ & Lab & DDT & $\begin{array}{l}0.1- \\
252.0\end{array}$ & $9.2-99.5$ & $\begin{array}{l}\text { Equil, } \\
22-28\end{array}$ & $\begin{array}{l}0.8,1.6,3.2 \\
6.4,9.6\end{array}$ & 900 & $\begin{array}{c}0.595-2.38 \\
0.074-0.177 \\
\end{array}$ & $\begin{array}{l}\text { Aquacarb } \\
\text { RS }\end{array}$ & Unspecified & $\begin{array}{l}\text { Tomaszewski et al. } \\
(2007 ; 2008)\end{array}$ \\
\hline $\begin{array}{l}\text { Aqc, biom, } \\
\text { bo }\end{array}$ & $\begin{array}{l}\text { Lab, } \\
\text { field }\end{array}$ & PCB & 2.0 & $\begin{array}{c}24.0- \\
94.6\end{array}$ & Equil, 28 & 3.4 & 935 & $0.074-0.297$ & TOG®-NDS & Unspecified & $\begin{array}{l}\text { Cho et al. (2007); } \\
\text { Tomaszewski and } \\
\text { Luthy (2008) }\end{array}$ \\
\hline $\begin{array}{l}\text { Aqc, biom, } \\
\text { bo }\end{array}$ & $\begin{array}{l}\text { Lab, } \\
\text { field }\end{array}$ & PCB & $\begin{array}{l}1.35- \\
1.62\end{array}$ & $\begin{array}{r}13.0- \\
100.0\end{array}$ & Equil, 28 & $2.1,3.2$ & 935 & $0.074-0.297$ & TOG®-NDS & Unspecified & Cho et al. (2009) \\
\hline
\end{tabular}


Table 1. AC amendment studies conducted in sediments (continued)

\begin{tabular}{|c|c|c|c|c|c|c|c|c|c|c|c|}
\hline Endpoint & $\begin{array}{l}\text { Study } \\
\text { type }\end{array}$ & Pollutant & $\begin{array}{l}\text { Sediment } \\
\text { conc. }\end{array}$ & Reduction & $\begin{array}{l}\text { Exposure } \\
\text { time }\end{array}$ & AC conc. & $\begin{array}{l}\text { Surface } \\
\text { area }\end{array}$ & Particle size & Trade name & AC-type & Reference \\
\hline & & & {$\left[\mathrm{mg} \mathrm{kg}^{-1}\right]$} & {$[\%]$} & [days] & [\%] & {$\left[\mathrm{m}^{2} \mathrm{~g}^{-1}\right]$} & {$[\mathrm{mm}]$} & & & \\
\hline Aqc, bo & Lab & $\mathrm{PAH}$ & $\begin{array}{l}9.0- \\
161.0\end{array}$ & $\begin{array}{l}(-11.1)- \\
98.2\end{array}$ & 28 & 2 & n.a. & $0.037-0.15$ & n.a. & Unspecified & $\begin{array}{l}\text { Cornelissen et al. } \\
(2006 b)\end{array}$ \\
\hline Aqc, biom & Lab & $\begin{array}{l}\text { PAH, } \\
\text { PCB }\end{array}$ & $8.0-9.9$ & $\begin{array}{c}10.0- \\
92.0\end{array}$ & $28-180$ & 3.4 & 940 & $0.075-0.3$ & $\begin{array}{l}\text { TOG® } \\
50 \times 200^{a}\end{array}$ & Unspecified & $\begin{array}{l}\text { Zimmerman et al. } \\
(2004)\end{array}$ \\
\hline $\begin{array}{l}\text { Aqc, biom, } \\
\text { bo }\end{array}$ & Lab & $\begin{array}{l}\text { PAH, } \\
\text { PCB }\end{array}$ & $8.0-9.9$ & $\begin{array}{l}(-15.0)- \\
97.3\end{array}$ & $14-56$ & $\begin{array}{l}0.34,1.7 \\
3.4\end{array}$ & 938 & $\begin{array}{l}0.075-0.3 \\
0.025-0.075\end{array}$ & TOG & Unspecified & $\begin{array}{l}\text { Zimmerman et al. } \\
\text { (2005) }\end{array}$ \\
\hline Aqc & Lab & PCB & 9.9 & $0.0-66.7$ & 28 & 3.4 & 1100 & $\begin{array}{l}0.42-1.7 \\
0.075-0.25\end{array}$ & $\mathrm{~F} 400$ & Unspecified & $\begin{array}{l}\text { Zimmerman et al. } \\
(2005)\end{array}$ \\
\hline$\overline{A q c}$ & Lab & PCB & 1250.0 & $\begin{array}{c}95.0- \\
98.0\end{array}$ & $28-540$ & 2 & 938 & $0.07-0.3$ & TOG & Unspecified & Werner et al. (2005) \\
\hline$\overline{A q c}$, bo & Lab & PCB & 0.3 & 87.4 & 28 & $\begin{array}{l}0.4,1.61 \\
1.85,2.6\end{array}$ & 938 & $0.07-0.3$ & TOG® & Unspecified & $\begin{array}{l}\text { Sun and Ghosh } \\
(2008)\end{array}$ \\
\hline$\overline{A q c}, \mathrm{bo}$ & Lab & PCB & 9.9 & $0-100$ & 28 & 3.4 & 1000 & $\begin{array}{c}0.07-0.3 \\
0.063-0.105 \\
0.105-0.25\end{array}$ & TOG & Unspecified & Millward et al. (2005) \\
\hline Bo & Lab & PCB & 1.2 & 95.0 & 28 & 3.4 & 940 & $0.074-0.297$ & $\begin{array}{l}\text { TOG } \\
50 \times 200\end{array}$ & Unspecified & $\begin{array}{l}\text { Janssen et al. } \\
(2010)\end{array}$ \\
\hline Bo & Lab & $\mathrm{PAH}$ & 1438.0 & $\begin{array}{r}83.0- \\
100.0\end{array}$ & 7 & 20 & 1100 & n.a. & n.a. & Unspecified & Burgess et al. (2009) \\
\hline$\overline{A q c}$ & Lab & $\mathrm{PAH}$ & $\begin{array}{l}2.0- \\
161.0\end{array}$ & $\begin{array}{c}71.9- \\
99.4\end{array}$ & 78 & $\begin{array}{l}0.2,0.5,2 \text {, } \\
4,\end{array}$ & n.a. & $0.037-0.149$ & n.a. & Unspecified & $\begin{array}{l}\text { Cornelissen et al. } \\
(2006 a)\end{array}$ \\
\hline $\begin{array}{l}\text { Aqc, biom, } \\
\text { bo }\end{array}$ & Lab & PCB & 6.8 & $\begin{array}{r}0.0- \\
100.0\end{array}$ & $1-28$ & 2.6 & 938 & $0.075-0.3$ & n.a. & Unspecified & $\begin{array}{l}\text { Sun and Ghosh } \\
(2007)\end{array}$ \\
\hline
\end{tabular}

Aqc: aqueous concentration; biom: biomimetic; bo: benthic organism; BT: butyltins (mono-, di-, tributyltin); conc.: concentration; DDT: $\Sigma$ DDT (dichloro- diphenyltrichloroethane (DDT), dichloro- diphenyl- dichloroethene (DDE), dichloro-diphenyl-dichloroethane (DDD)); Equil: equilibrium; GAC: granulated activated carbon; Lab: laboratory: n.a.: not available; PAC: powdered activated carbon; PAH: polycyclic hydrocarbons; PCB: polychlorinated biphenyls; PHE:

phenanthrene 
Table 2. AC amendment studies conducted in soils

\begin{tabular}{|c|c|c|c|c|c|c|c|c|c|c|c|}
\hline Endpoint & $\begin{array}{r}\text { Study } \\
\text { type }\end{array}$ & Pollutant & Soil conc. & Reduction & $\begin{array}{l}\text { Exposure } \\
\text { time }\end{array}$ & AC conc. & $\begin{array}{l}\text { Surface } \\
\text { area }\end{array}$ & Particle size & Trade name & AC type & Source \\
\hline & & & {$\left[\mathrm{mg} \mathrm{kg}^{-1}\right]$} & {$[\%]$} & [days] & {$[\%]$} & {$\left[\mathrm{m}^{2} \mathrm{~g}^{-1}\right]$} & {$[\mathrm{mm}]$} & & & \\
\hline Aqc & Lab & $\mathrm{PAH}$ & $38.0-5500.0$ & $63.0-99.0$ & 42 & 2 & $0.015-0.15$ & 1300 & n.a. & PAC & Brandli et al. (2008) \\
\hline Tot & Lab & $\mathrm{Nic}$ & $500.0-2000.0$ & $18.8-75.3$ & 120 & $\begin{array}{l}0.25 \\
0.75,1 \\
\end{array}$ & 0.035 & n.a. & DARCO & PAC & $\begin{array}{l}\text { Vasilyeva et al. } \\
\text { (2001) }\end{array}$ \\
\hline Tot & Lab & Nic & $500.0-2000.0$ & $32.7-81.0$ & 120 & $1 \& 5$ & $0.035 \& 10$ & n.a. & $\begin{array}{c}\text { DARCO \& } \\
\text { shreddered } \\
\text { corn plants }\end{array}$ & PAC & $\begin{array}{l}\text { Vasilyeva et al. } \\
(2001)\end{array}$ \\
\hline Biom & Lab & Nic & 2000.0 & $\begin{array}{r}73.3- \\
100.0 \\
\end{array}$ & 120 & 1 & 0.035 & n.a. & DARCO & PAC & $\begin{array}{l}\text { Vasilyeva et al. } \\
(2006)\end{array}$ \\
\hline $\begin{array}{l}\text { Biom, plant, } \\
\text { tot }\end{array}$ & Lab & PCB & $1585.0-4190.0$ & $0.0-66.7$ & 1170 & $0.5,3.5$ & $0.001-0.1$ & 1000 & SKT-6A & PAC & $\begin{array}{l}\text { Vasilyeva et al. } \\
(2010)\end{array}$ \\
\hline Plant & Field & Pest & $0.6-1.1$ & $21.1-98.1$ & $720-1440$ & $\begin{array}{c}0.0084 \\
0.0167 \\
0.0336\end{array}$ & 0.279 & n.a. & $\begin{array}{l}\text { Aqua Nuchar } \\
\text { A }\end{array}$ & PAC & Rydrych (1985) \\
\hline Biom, plant & Lab & Pest & 0.07 & $10-75$ & $77-91$ & $\begin{array}{c}0.02 \\
0.04 \\
0.08 \\
\end{array}$ & $\begin{array}{r}0.007- \\
0.027\end{array}$ & 1200 & $\begin{array}{l}\text { Norit@ SX } \\
\text { Ultra }\end{array}$ & PAC & $\begin{array}{l}\text { Hilber et al. (2009a; } \\
\text { 2009b) }\end{array}$ \\
\hline Plant & field & HCB & 15.3 & 31.9 & 90 & 0.04 & $0.01-0.15$ & 800 & n.a. & $\begin{array}{l}\text { Unspeci- } \\
\text { ffied }\end{array}$ & $\begin{array}{l}\text { Mandl and Lindner } \\
\text { (1999) }\end{array}$ \\
\hline Plant & Lab & Pest & $0.1-4.0$ & $0.0-80$ & 14 & $\begin{array}{l}2.6,5.2 \\
7.3,43.8\end{array}$ & n.a. & n.a. & $\begin{array}{l}\text { Waste } \\
\text { activated } \\
\text { carbon }\end{array}$ & $\begin{array}{l}\text { Unspeci- } \\
\text { fied }\end{array}$ & Guo et al. (1991) \\
\hline Biom & Lab & $\mathrm{PAH}$ & 10.0 & $25.1-63.2$ & 20 & $\begin{array}{r}0.1,0.5 \\
1,2.5,5 \\
\end{array}$ & 0.021 & n.a. & n.a. & $\begin{array}{l}\text { Unspeci- } \\
\text { fied }\end{array}$ & Rhodes et al. (2008) \\
\hline Aqc & Lab & $\mathrm{PAH}$ & $38.0-5500.0$ & $4.0-64.0$ & 42 & 2 & $0.43-1.7$ & $1050-1200$ & n.a. & GAC & Brandli et al. (2008) \\
\hline $\begin{array}{l}\text { Aqc, biom, } \\
\text { plant, tot }\end{array}$ & Lab & Nic, PCB & $1700-6250$ & $5.0-100.0$ & $420-640$ & $0.5,1,7$ & n.a. & n.a. & Agrosorb & GAC & $\begin{array}{l}\text { Vasilyeva et al. } \\
\text { (2006) }\end{array}$ \\
\hline $\begin{array}{l}\text { Biom, plant, } \\
\text { tot }\end{array}$ & Lab & PCB & 4190.0 & $5.0-96.2$ & 1170 & 2,7 & $0.4-1.5$ & 880 & AG1 & GAC & $\begin{array}{l}\text { Vasilyeva et al. } \\
(2010)\end{array}$ \\
\hline Plant & Lab & Pest & 50.0 & $0.0-88.9$ & 35 & $0.1,0.5,1$ & n.a. & $27 \& 566$ & $\begin{array}{l}\text { Biochar } 450 \text { \& } \\
850\end{array}$ & Biochar $^{a}$ & Yu et al. (2009) \\
\hline
\end{tabular}

${ }^{\mathrm{a} p y r o l y s i s}$ at 450 and $850^{\circ} \mathrm{C}$

Aqc: aqueous concentration; biom: biomimetic; conc.: concentration; equil: equilibrium; GAC: granulated activated carbon; Lab: laboratory; n.a.: not available; Nic; nitro compounds (trinitro toluene (TNT), dichloroaniline); PAC: powdered activated carbon; PAH: polycyclic hydrocarbons; Pest: pesticides (alachlor, atrazine, carbofuran, chlorpyrifos, dieldrin, hexaclorobenzene (HCB), metribuzin); PCB: polychlorinated biphenyls; tot: total extraction 
Table 3. Overview of AC amendment studies in the published literature

\begin{tabular}{lllll}
\hline Sediments & Total & Lab & Field & Both \\
\hline Number & 17 & 14 & 3 & 3 \\
\hline AC Type & PAC & GAC & Coke breeze & Fly ash \\
Number & 15 & 2 & 2 & 2 \\
Conc. range [\%]dw & $0.3-20.0$ & $2.0-3.4$ & $3.4-8.5$ & $3.5-20$ \\
\hline Soils & Total & Lab & Field & Both \\
\hline Number & 13 & 10 & 3 & - \\
\hline AC type & PAC & GAC & WAC & Biochar \\
Number & 10 & 3 & 1 & 1 \\
Conc. range [\%]dw & $>0.1-12.8$ & $1.0-7.0$ & $2.6-43.7$ & $0.1-1.0$ \\
\hline
\end{tabular}

Lab: laboratory study, Field: field study, PAC: powdered activated carbon,

GAC: granulated activated carbon, WAC: waste activated carbon

For soils, Rydrych (1985), Mandl and Lindner (1999), and Hashimoto (2007) brought out the charcoal as aqueous suspension in the field. Berglund et al. (2004) applied the charcoal suspension to microplots of $20 \times 20 \times 10 \mathrm{~cm}$ with a syringe of $50 \mathrm{~mL}$. The authors state a rapid incorporation of the AC into the soil with minimal disturbance to the forest floor. Although this amendment technique fulfils the above mentioned requirements, we doubt this method is practicable on a larger scale. Of the papers reviewed here, these are the only publications which describe the application of $A C$ in the fields. In soil laboratory studies, AC was either mixed by glove protected hands (Hilber et al., 2009b), with a stainless spoon (Rhodes et al., 2010), by rotary shaker (Yu et al., 2009), or by shaking incubators (Choi et al., 2007). Again, quite a few papers do not elaborate on their amendment technique at all.

\section{EVALUATION OF AC AMENDMENTS}

The bioavailability of a compound in a contaminated soil or sediment environment can be assessed directly by residue analysis in target organisms like mussels, worms, plants, etc. Further, the contaminants can be sampled passively with non-depletive methods by devices like polyoxymethylene (POM) plates, polyethylene (PE) strips, and many more. Such materials assess the chemical activity of a compound in the aqueous phase of soils or sediments. In the following, these non-depletive extraction methods are categorized as "aqueous concentration". This term also comprises liquid-liquid extractions (LLE) where some researchers removed the colloids before LLE using the flocculation method by Ghosh et al. (2000). Depletive methods comprise sorbents like semipermeable membrane devices (SPMD), Tenax®, XAD or other beads. According to Reichenberg and Mayer (2006) depletive sampling is controlled by the accessibility and the desorption kinetics of the sample matrix rather than by the strength of the solvent. We categorize the depletive extraction methods as "biomimetics" in this review. Note that the difference between non-depletive and depletive sorbents is determined by their sorption capacities. For more detailed information about the underlaying theory of sorption/desorption processes, especially in the presence of black carbon (BC), we refer to the literature (e.g., Cornelissen et al., 2005, Koelmans et al., 2006).

In the following, we use the term "endpoint" for all these forms or concepts of bioavailability. Toxicological effects, e.g., reduced plant growth, make up yet another type of endpoint considered in this review. We expressed the difference of the endpoint in the treated matrix and in the control as percentage of the control treatment, which represented $100 \%$. Thus, the percentage of reduction is a quantitative measure for the efficiency of the AC amendment, and is the dependent variable in the whole discussion. This form of presentation was selected to unite the otherwise very diverse studies. From this, it is clear, that we could not include some data from studies like the one from Vasilyeva et al. (2001) who indicated the success of the AC amendment in microbial or plant growth or the one from Rhodes et al. (2010) who quantified the mineralisation of phenanthrene in soils in amended and unamended soil. Depending on the perspective and intention behind AC amendment, a reduced mineralisation may be considered either a success or a failure.

In the works of Vasilyeva et al. $(2001 ; 2006 ; 2010)$ total extractions were used to indicate the efficiency of AC amendments. However, this extraction method is difficult to reconcile with the notion of bioavailability as introduced above. Nevertheless, these data were included in the review, because in the 2001 and the 2006 studies, the researchers freshly spiked the soil with 2,4,6-trinitrotoluene (TNT) and just compared the decrease of the total extractable concentration of the unamended with the AC 
amended soil. In the 2006 and 2010 studies, the soil was historically contaminated and the authors wanted to show the extremely high persistence of polychlorinated biphenyls (PCB) via total extraction. As independent variable we chose the pollutant concentration in the matrix. Because of the adsorptive character of $A C$, we normalized this value in sediments by dividing the pollutant concentration with the AC concentration multiplied by the specific surface area. Hence, the x-axis in Figure 1 for sediments has the unit [ $\mu \mathrm{g}$ pollutant $\mathrm{m}^{-2} \mathrm{AC}$ ]. For most of the studies performed with soil, the AC specific surface area was not available. Therefore, and as a second best option only, we divided the pollutant concentration by the more frequently reported $A C$ concentration. Consequently, the resulting unit of the $\mathrm{x}$-axis in Figure 2 for soils studies is expressed as [mg pollutant $\mathrm{g}^{-1} \mathrm{AC}$ ].

\section{Reduction of endpoint's concentration in sediments}

In Figure 1 the reductions are classified according to endpoints (Figure 1, A) and compounds (Figure $1, B)$. In theory, because of the adsorptive nature of $A C$, one would expect the degree of reduction to be negatively correlated with the relative amount of pollutant present. However, no such trend is discernable. Nevertheless, some $68 \%$ of the data showed considerable reductions of $>50 \%$ of the pollutant availability due to $A C$ amendment. But, in quite a number of cases, $A C$ amendment did not seem to be successful. In the following, we exemplarily discuss selected problematic cases (i.e., reductions $<50 \%$ ) both at low and at high pollutant to $\mathrm{AC}$ ratio and possible reasons for amendment failure.

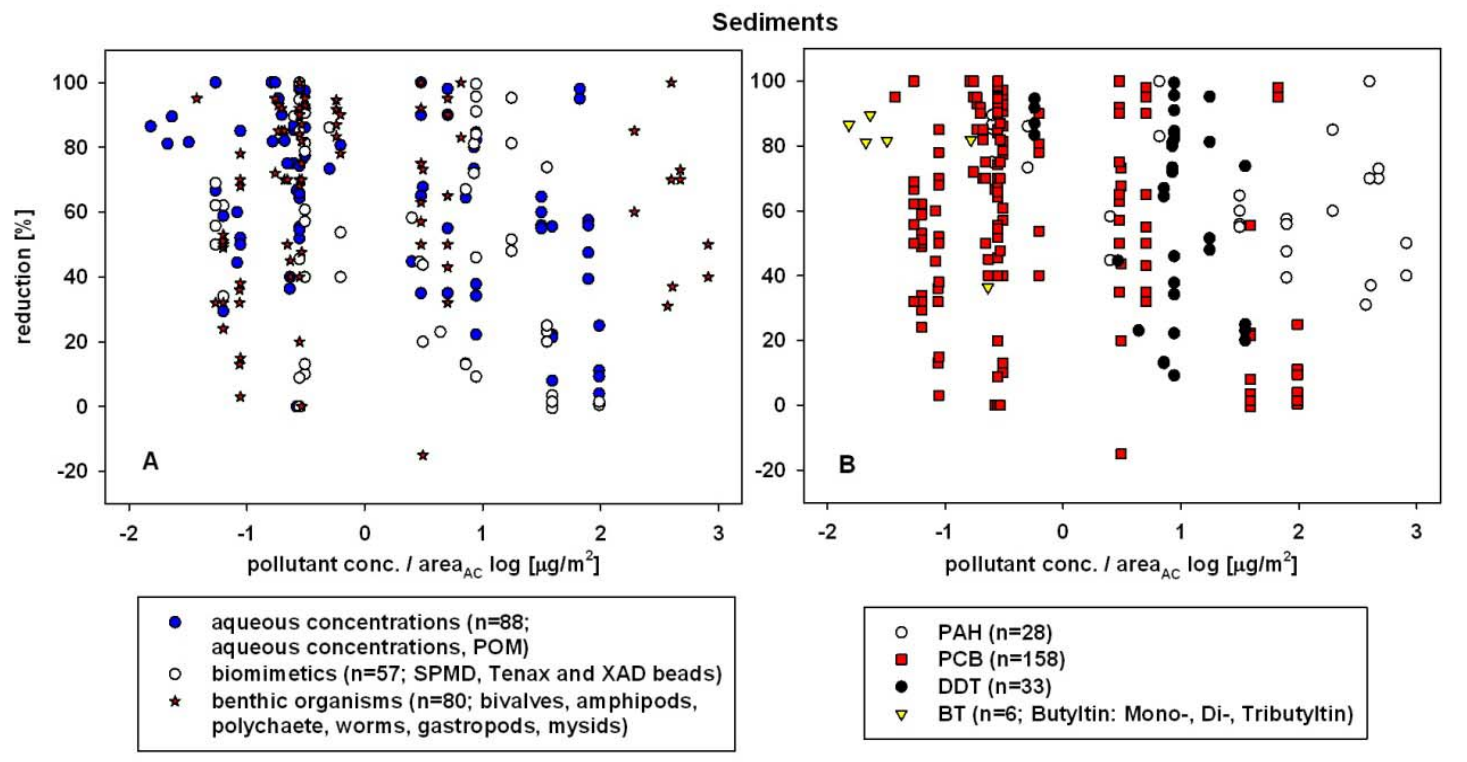

Figure 1. Reductions of organic contaminants classified by endpoints $(A)$ and pollutants $(B)$ versus ratios of pollutant concentrations over $A C$ area multiplied by $A C$ concentration $\left[\mu \mathrm{g} \mathrm{m}^{-2}\right]$ in sediments. Reduction in endpoints are expressed in [\%] of amended in comparison to the unamended sediments

Low reductions were found in some of the data at high pollutant to $A C$ ratios (Figure 1, x: $1.6-2.0 \log$ $\left[\mathrm{g} \mathrm{m} \mathrm{m}^{-2}\right]$ ). For instance, in the study of Zimmerman et al. (2004), the aqueous concentrations of PCB and polycyclic aromatic hydrocarbons (PAH) in the coke breeze amended sediment were successfully reduced by $A C$ amendment, but quite a part of the data showed low binding efficiency. Especially the PCB concentrations were merely reduced (y: $8-25 \%)$. The coke breeze with a rather low specific surface area as low as $3 \mathrm{~m}^{2} \mathrm{~g}^{-1}$ (Table 1) might therefore be overloaded. In fact, using molecular surface areas of 200 or more $\AA^{2}$ (Bucheli and Gustafsson, 2000), together with pollutant concentrations and AC areas as given by Zimmerman et al. (2004), it turns out that monolayer coverage is largely exceeded in the coke breeze. We also consider a desorption from the bulky pollutant layer of the coke breeze responsible for the lower reductions in aqueous concentrations of the PCB in 180 days of AC treatment time compared to the 28 days. The adsorption of the PCB multiple layers might not have been as strong as in the mono-layer resulting in a desorption of the pollutant after some time. 
Limited reductions at low pollutant concentration to $A C$ surface areas are generally more difficult to rationalize. In this case, sorbent overloading is not a likely reason for amendment failure. The bottom left part of Figure 1 depicts the data of Millward et al. (2005) (x: $\left.-0.5 \log \left[\mu \mathrm{g} \mathrm{m}^{-2}\right], \mathrm{y}: 0 \%\right)$. In this study, the AC treatment time was 180 days, after which the amphipod Leptocheirus plumulosus and the polychaete Neanthes arenaceodentata were added and exposed for 28 days. Both organisms showed high reduction of accumulated pollutants $(>50 \%$ ) in the case of TOG (see Table 1) amended sediment. In contrast, the coke breeze slurry did not result in any such reduction, although the $x$-values were the same or even a bit lower.

In the same area (Figure 1, $\mathrm{x}:-1 \log \left[\mu \mathrm{g} \mathrm{m}^{-2}\right], \mathrm{y}: 3-38 \%$ ), we find results from a study of Sun and Ghosh (2008). Here, the reason for relatively low reductions shown by the bioaccumulation factor (BCF) of worms (Lumbriculus variegatus) of the Niagara River could be the pollutant's molecular structure. Although the $A C$ amendment was only $0.4 \%$, the di-, tri-, and tetra-chlorinated biphenyls (CB) showed a successful PCB reduction in the worms but not the heavier homologues, i.e., the penta-, hexa-, and hepta-CB. This low performance of the heavy CB could be due to the higher $\mathrm{K}_{\mathrm{O}}$ of the higher chlorinated PCBs than for the low chlorinated ones demanding for longer equilibrium time. The authors also related the log $\mathrm{K}_{\mathrm{O}}$ w with the log BCF and could show a positive correlation for tri- to hepta-CB $\left(r^{2}=0.61\right)$. Moreover, the figure in their supporting information shows that the uptake by the worms scatters stronger for heavy homologues like hepta-CB.

So far we only looked at the extreme ends of the $x$-axis with low reductions $(<50 \%)$, and related these findings to possible limitations due to pollutants and AC (amendment) properties. In this paragraph, we will focus on the different behaviour of benthic organisms. In another study of Zimmerman et al. (2005), $N$. arenaceodentata took up more PCB in the amended than in the unamended sediment (Figure 1, x: $0.5 \log \left[\mu \mathrm{g} \mathrm{m}^{-2}\right], \mathrm{y}:-15 \%$ ). However, in the same study, L. plumulosus in the $0.34 \%$ amended sediment showed a reduced uptake of PCBs by $73 \%$ (Figure $1, \mathrm{x}: 0.5 \log \left[\mu \mathrm{g} \mathrm{m}^{-2}\right]$ ). In a study by Cornelissen et al. (2006b) (not in Figure 1 because of missing specific surface area of the PAC), no significant reduction was achieved in two $2 \%$ PAC amended sediments for the gastropod Hinia reticulata, whereas the polychaete Nereis diversicolor had a reduced BSAF of six to seven comparing to the control. The authors hypothesise that either site-specific evaluations of the AC amendment are necessary, by using several site-relevant benthic organisms, or that the physiology of $H$. reticulata caused artifactually high BSAF values in the presence of AC.

Besides the different uptake mechanisms and feeding behaviours of benthic organisms (diffusion through skin, uptake through gills or, in case of worms, ingestion and/or diffusion through skin), the time of $A C$ treatment and endpoint exposure is crucial. The time of $A C$ treatment varied from two minutes (Sun and Ghosh, 2007) to 780 days (Tomaszewski et al., 2007). In some articles, this information was not available (Voparil et al., 2004; Cornelissen et al., 2006a; Burgess et al., 2009). The work of Sun and Ghosh (2007) was specifically investigating the time of AC treatment. Mixing of two minutes showed a diminished reduction of PCB uptake into two worms (L. variegatus; Figure $1, \mathrm{x}$ $0.6 \log \left[\mu \mathrm{g} \mathrm{m}^{-2}\right], \mathrm{y}: 70 \%$ and $92 \%$ ), as well as a higher variation in the uptake compared to a mixing of one month. The endpoint exposure time varied in the same range as the time of AC treatment from 1 540 days (Table 1). The shortest exposure time is again mentioned in the study of Sun and Ghosh (2007), which was one day. The longest exposure time is mentioned by Werner et al. (2005). The authors state that these tests show that PCB sequestration with AC improves with contact time and is not diminished by prolonged mixing with sediment.

\section{Reduction endpoints in soils}

Similar to the situation in sediments (Figure 1), no specific relation between the reduction in the endpoint and the pollutant to AC ratio is discernable in Figure 2. Half $(52 \%)$ of the data showed considerable reductions of $>50 \%$ due to $A C$ amendment. So far, the reduction was expressed as the pollutant concentration in the respective endpoint. Soil researchers also worked with plants and indicated the efficiency of the AC amendment as toxicity reduction. Thus, the success of the soil treatment should result, e.g., in a reduced germination inhibition or the difference in biomass production or yield compared to the unamended control. However, a toxicological endpoint is only indicative within the dynamic range of the dose-response curve. Any pollutant reduction by AC amendment that takes place at the very low or very high end of this curve will not be discernable, meaning that this endpoint will not be reduced relative to the control. This may be the reason for most of the apparently non-successful applications of AC (majority of the low reduction results have plant endpoints), as discussed in the following two examples at high and low pollutant to AC ratio. 


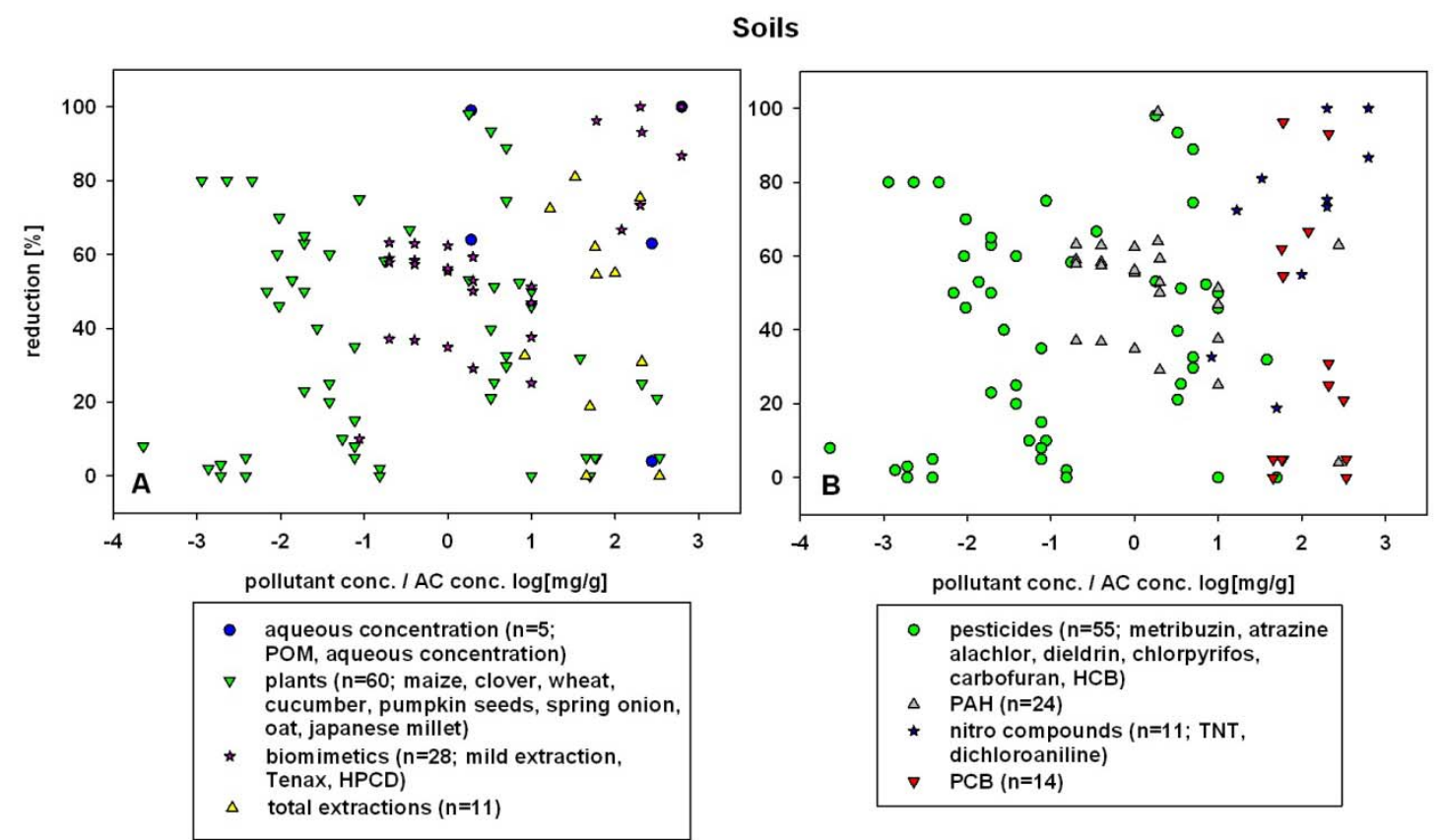

Figure 2. Reductions of organic contaminants classified by endpoints $(A)$ and pollutants $(B)$ versus ratios of pollutant over $A C$ concentrations $\left[\mathrm{mg} \mathrm{g}^{-1}\right]$ in soils. Reduction in endpoints are expressed in [\%] of amended in comparison to the unamended soils

We first focus on the bottom right area of Figure 2, i.e., where data with high pollutant to $\mathrm{AC}$ ratios and low reductions in endpoints are located. In the study of Vasilyeva et al. (2010), the reductions varied from $5-25 \%$ in PCB polluted soil (Figure 2; x: $1.6-2.3 \mathrm{log}\left[\mathrm{mg} \mathrm{g}^{-1}\right]$ ). The PCB concentrations from two heavily polluted industrial sites were 1585 and $4190 \mathrm{mg} \mathrm{kg}^{-1}$ (Table 2). Thus, the reason for the reduced germination inhibition in clover could simply be that this endpoint was not sensitive. In addition, at such high concentrations, an overload of the GAC and PAC (Table 2) amended soil may have taken place. Finally, although the treatment time was very long (1170 days), the binding and thus the efficiency of the $A C$ might have been very slow due to mass transfer limitations in the unsaturated zone and, consequently, reduced sorption at AC. Thus, unsaturated water conditions might be responsible for the low performance of the $A C$ in soils.

The data grouped the bottom left corner of Figure 2 (x: $\left.(-3.6)-(-0.8) \log \left[\mathrm{mg} \mathrm{g}^{-1}\right]\right)$ largely consists of results of pesticide uptake by plants from polluted soils. The plants studied by Guo et al. (1991) were oat and Japanese millet, and the investigated herbicides atrazine and alachlor. Successful reductions of pesticide uptake was only achieved when adding high concentrations $(43.8 \%)$ of waste AC (WAC). Moreover, the material was priorily used in filtration processing of corn sweetener prior to soil amendment, and sorption sites may thus have been occupied by other pollutants already. In all other low sorption performances of AC material, similar reasons as discussed above are probably responsible for $A C$ amendment failure.

\section{FACTORS POTENTIALLY REDUCING THE EFFICIENCY OF AC AMENDMENT AND OTHER SIDE EFFECTS}

Although less invasive than many other reclamation techniques, AC amendment may also have unwanted or detrimental effects to soil and sediment ecosystems, and thereby diminish the positive effect of reduced pollutant exposure.

A series of additional factors not covered in the preceding sections may influence the effectivity of AC amendment. Addition of $A C$ may lead to a fast and pronounced reduction of pollutant exposure. However, elevated AC concentrations may potentially influence the physical and chemical characteristics of soils and sediments, such as the physical (clogging) or chemical (hydrophobicity) alteration of soil pores, water permeability (Strijakova and Vasilyeva, 2006), pH (Rydrych, 1985; Berglund et al., 2004), redox conditions, etc. Further, it may lead to decreased nutrient availability for plants (Lehmann et al., 2003; Berglund et al., 2004; Hilber et al., 2009b), benthic (Jonker et al., 2009) 
and soil organisms, or to the release of pollutants originally bound to the amended sorbent like heavy metals or organic pollutants (Jonker and Koelmans, 2002).

Another yet largely unanswered question is the one about AC stability in soils and sediments (Murphy et al., 2006). Because this remediation technique is still rather juvenile, long term data beyond a few years are completely lacking. Some researchers state the recalcitrant properties of BC in general (Cheng et al., 2008), while others doubt its longevity (Zimmerman, 2010). Biochar is mainly used to sequester carbon and thus increase the fertility of soils, but also used to bind organic pollutants in soils (Yu et al., 2009). Models revealed a 100 year losses of $3-26 \%$ and biochar $C$ half-lives ranging from $10^{2}-10^{7}$ years. Such losses would be quite considerable, but commercial AC might be more condensed due to higher production temperature $\left(1000^{\circ} \mathrm{C}\right)$ than in the biochar production $\left(250-650{ }^{\circ} \mathrm{C}\right)$.

Little is known about the influence of physical dislocation of AC from the site of application. In sediments, surfacially applied AC may be translocated by water currents, and surface runoff or leaching may lead to removal of $A C$ in soils. Consequently, bound pollutants may be co-mobilized and the pollution spread to neighbouring environment (Zimmerman et al., 2008). So far, the aforementioned researchers stated that sediment remains cohesive and will maintain the AC in place under normal conditions, and that during extreme storm events only minimal erosion will occur.

Natural organic matter is known to cause attenuation effects on various forms of $\mathrm{BC}$ (Cornelissen et al., 2005) and AC (Rydrych, 1985; Pignatello et al., 2006), leading to drastically reduced sorption capacities and strength. This effect has not yet been investigated quantitatively and over a prolonged period of time for $\mathrm{AC}$ amendment.

Millward et al. (2005) and Jonker et al. (2009) reported on (indirect) harmful effects of AC to sediment organisms. Powdered $A C$ can be toxic to aquatic invertebrates and other benthic organisms may physically avoid AC enriched sediments. Also $L$. variegatus showed a decreased lipid content in AC amended sediments probably due to decreased excretion rates, because AC disturbed their feeding behaviour.

Finally, a whole series of other studies found positive effects of $A C$ on pollutant exposure. A quite exotic use of $A C$, which is, however, fully in accordance with the positive effects described above, is to bind celery residues left on the field which have an allelopathic effect on lettuce, thereby increasing its growth rate (Shilling et al., 1992). The researchers could show an increase of lettuce grown in celery residues happened when AC was amended to the field. Gong et al. (2007) used the adsorption capacity of $A C$ to clean vegetable oil which was used for soil remediation from $\mathrm{PAH}$. Another positive effect of $A C$ can be the reduced toxicity of pollutants to soil microorganisms, creating favourable conditions for plant growth and accelerated microbial degradation of TNT (Vasilyeva et al., 2001).

\section{CONCLUSION AND OUTLOOK}

Overall, AC amendment should today be recognized as an amendment technique still at its infancy. Although promising in general, as indicated by substantial reductions of pollutant exposures in majority of the cases, a worrying fraction of incidences with unsatisfactory amendment outcome indicates that the determining parameters responsible for efficient application of this technique need to be identified and more systematically evaluated in the future. Specific questions to be addressed include: 1) the nature of AC: not all materials are equally well suited, 2) the long-term stability and sequestering potential of $A C, 3$ ) the optimal pollutant to $A C$ fractions to be applied, 4) the time to reach equilibrium after amendment, and, 5) the selection of relevant endpoints, the interrelation between different depletive and non-depletive proxies, and their representativeness for actual ecotoxicological endpoints. These factors will also be affected by site-specific characteristics, such as the nature of the pollutants, saturated vs. unsaturated conditions in soils, and, last but not least, the envisaged use of a given site and the corresponding acceptable degree of remaining pollutant exposure after reclamation. Promising efforts to optimize AC amendments and a switch from lab-based to actual field studies are currently ongoing. We curiously await the results of current and future studies and hope that this review contributes to 1) raise the awareness of scientists and engineers for critical aspects of this amendment technique, and 2) the refinement of experimental conditions, with a view to consistently and significantly diminish exposure of environment and humans suffering from chemical pollution.

\section{REFERENCES}

Bartelt-Hunt S.L., Culver T.B., Smith J.A., Matott L.S. and Rabideau A.J. (2006), Optimal design of a compacted soil liner containing sorptive amendments, Journal of Environmental Engineering-ASCE, 132, 769-776. 
Berglund L.M., DeLuca T.H. and Zackrisson O. (2004), Activated carbon amendments to soil alters nitrification rates in Scots pine forests, Soil Biology and Biochemistry, 36, 2067-2073.

Bes C. and Mench M. (2008), Remediation of copper-contaminated topsoils from a wood treatment facility using in situ stabilisation, Environmental Pollution, 156, 1128-1138.

Brandli R.C., Breedveld G.D. and Cornelissen G. (2009), Tributyltin sorption to marine sedimentary black carbon and to amended activated carbon, Environmental Toxicology and Chemistry, 28, 503-508.

Brandli R.C., Hartnik T., Henriksen T. and Cornelissen G. (2008), Sorption of native polyaromatic hydrocarbons (PAH) to black carbon and amended activated carbon in soil, Chemosphere, 73, 18051810.

Bucheli T.D. and Gustafsson O. (2000), Quantification of the soot-water distribution coefficient of PAHs provides mechanistic basis for enhanced sorption observations, Environmental Science and Technology, 34, 5144-5151.

Burgess R.M., Perron M.M., Friedman C.L., Suuberg E.M., Pennell K.G., Cantwell M.G., Pelletier M.C., Ho K.T., Serbst J.R. and Ryba S.A. (2009), Evaluation of the effects of coal fly ash amendments on the toxicity of a contaminated marine sediment, Environmental Toxicology And Chemistry, 28, 26-35.

Castelo-Grande T., Augusto P.A., Monteiro P., Estevez A.M. and Barbosa D. (2010), Remediation of soils contaminated with pesticides: a review, International Journal of Environmental Analytical Chemistry, 90, 438-467.

Cheng C.H., Lehmann J., Thies J.E. and Burton S.D. (2008), Stability of black carbon in soils across a climatic gradient, Journal of Geophysical Research-Biogeosciences, 113, G02027.

Cho Y.M., Ghosh U., Kennedy A.J., Grossman A., Ray G., Tomaszewski J.E., Smithenry D.W., Bridges T.S. and Luthy R.G. (2009), Field application of activated carbon amendment for in-situ stabilization of polychlorinated biphenyls in marine sediment, Environmental Science and Technology, 43, 38153823.

Cho Y.M., Smithenry D.W., Ghosh U., Kennedy A.J., Millward R.N., Bridges T.S. and Luthy R.G. (2007), Field methods for amending marine sediment with activated carbon and assessing treatment effectiveness, Marine Environmental Research, 64, 541-555.

Choi J.W., Kim S.B. and Kim D.J. (2007), Desorption kinetics of benzene in a sandy soil in the presence of powdered activated carbon, Environmental Monitoring and Assessment, 125, 313-323.

Cornelissen G., Rigterink H., ten Hulscher,D.E.M., Vrind B.A., van Noort P.C.M. (2001), A simple Tenax® extraction method to determine the availability of sediment-sorbed organic compounds, Environmental Toxicology and Chemistry, 20, 706-711.

Cornelissen G., Gustafsson O., Bucheli T.D., Jonker M.T.O., Koelmans A.A., Van Noort P.C.M. (2005), Extensive sorption of organic compounds to black carbon, coal, and kerogen in sediments and soils: Mechanisms and consequences for distribution, bioaccumulation, and biodegradation, Environmental Science and Technology, 39, 6881-6895.

Cornelissen G., Breedveld G.D., Kalaitzidis S., Christanis K., Kibsgaard A. and Oen A.M.P. (2006a), Strong sorption of native PAHs to pyrogenic and unburned carbonaceous geosorbents in sediments, Environmental Science and Technology, 40, 1197-1203.

Cornelissen G., Breedveld G.D., Naes K., Oen A.M.P. and Ruus A. (2006b), Bioaccumulation of native polycyclic aromatic hydrocarbons from sediment by a polychaete and a gastropod: Freely dissolved concentrations and activated carbon amendment, Environmental Toxicology and Chemistry, 25, 2349-2355.

Ghosh U., Weber A.S., Jensen J.N. and Smith J.R. (2000), Relationship between PCB desorption equilibrium, kinetics, and availability during land biotreatment, Environmental Science and Technology, 34, 2542-2548.

Gong Z.Q., Alef K., Wilke B.M. and Li P.J. (2007), Activated carbon adsorption of PAHs from vegetable oil used in soil remediation, Journal of Hazardous Materials, 143, 372-378.

Guo L., Bicki T.J., Felsot A.S. and Hinesly T.D. (1991), Phytotoxicity of atrazine and alachlor in soil amended with sludge, manure and activated carbon, Journal of Environmental Science And Health Part B-Pesticides Food Contaminants and Agricultural Wastes, 26, 513-527.

Hashimoto Y. (2007), Reduction of dieldrin concentration in cucumber fruits using Cucurbita rootstocks and activated carbon, Journal of Pesticide Science, 32, 229-234.

Hilber I., Bucheli T.D., Wyss G.S. and Schulin R. (2009a), Assessing the phytoavailability of dieldrin residues in charcoal-amended soil using Tenax extraction, Journal of Agricultural and Food Chemistry, 57, 4293-4298. 
Hilber I., Wyss G.S., Mader P., Bucheli T.D., Meier I., Vogt L. and Schulin R. (2009b), Influence of activated charcoal amendment to contaminated soil on dieldrin and nutrient uptake by cucumbers, Environmental Pollution, 157, 2224-2230.

Janssen E.M.L., Croteau M.-N.I., Luoma S.N. and Luthy R.G. (2010), Measurement and modeling of polychlorinated biphenyl bioaccumulation from sediment for the marine polychaete Neanthes arenaceodentata and response to sorbent amendment, Environmental Science and Technology, 44, 2857-2863.

Jonker M.T.O. and Koelmans A.A. (2002), Sorption of polycyclic aromatic hydrocarbons and polychlorinated biphenyls to soot and soot-like materials in the aqueous environment: Mechanistic considerations, Environmental Science and Technology, 36, 3725-3734.

Jonker M.T.O., Suijkerbuijk M.P.W., Schmitt H. and Sinnige, T.L. (2009), Ecotoxicological effects of activated carbon addition to sediments, Environmental Science and Technology, 43, 5959-5966.

Koelmans A.A., Jonker M.T.O, Cornelissen G., Bucheli T.D., Van Noort P.C.M. and Gustafsson Ö. (2006), Black carbon: the reverse of its dark side, Chemosphere, 63, 365-377.

Lehmann J., da Silva J.P., Steiner C., Nehls T., Zech W. and Glaser B. (2003), Nutrient availability and leaching in an archaeological Anthrosol and a Ferralsol of the Central Amazon basin: fertilizer, manure and charcoal amendments, Plant and Soil, 249, 343-357.

Lowry G.V., Murphy P.J., Marquette, A. and Reible D., 2006. Sorbent-amended "active" sediment caps for in-place management of PCB-contaminated sediments, Contaminated Soils, Sediments and Water, 10, 379-391.

Mandl A. and Lindner W. (1999), Organochlorine pesticide residues in Styrian soils and seeds of the Styrian oil pumpkin: An inventory and a concept for their reduction, International Journal of Environmental Analytical Chemistry, 73, 1-13.

Millward R.N., Bridges T.S., Ghosh U., Zimmerman J.R. and Luthy R.G. (2005), Addition of activated carbon to sediments to reduce PCB bioaccumulation by a polychaete (Neanthes arenaceodentata) and an amphipod (Leptocheirus plumulosus), Environmental Science and Technology, 39, 28802887.

Murphy P., Marquette A., Reible D. and Lowry G.V. (2006), Predicting the performance of activated carboncoke-, and soil-amended thin layer sediment caps, Journal of Environmental Engineering-ASCE, 132, 787-794.

Pignatello J.J., Kwon S. and Lu Y.F. (2006), Effect of natural organic substances on the surface and adsorptive properties of environmental black carbon (char): Attenuation of surface activity by humic and fulvic acids, Environmental Science and Technology, 40, 7757-7763.

Reichenberg F. and Mayer P. (2006), Two complementary sides of bioavailability: Accessibility and chemical activity or organic contaminants in sediments and soils. Environmental Toxicology And Chemistry, 25, 1239-1245.

Rhodes A.H., Carlin A. and Semple K.T. (2008), Impact of black carbon in the extraction and mineralization of phenanthrene in soil, Environmental Science and Technology, 42, 740-745.

Rhodes A.H., McAllister L.E., Chen R. and Semple K.T. (2010), Impact of activated charcoal on the mineralisation of $14 \mathrm{C}$-phenanthrene in soils, Chemosphere, 79, 463-469.

Rydrych D.J. (1985), Inactivation of metribuzin in winter-wheat by activated carbon, Weed Science, 33, 229-232.

Shilling D.G., Dusky J.A., Mossler M.A. and Bewick T.A. (1992), Allelopathic potential of celery residues on lettuce, Journal of the American Society for Horticultural Science, 117, 308-312.

Strijakova E.R. and Vasilyeva G.K., 2006. Influence of activated carbon on soil fertility and quality of crops grown in contaminated soil, "-omics approaches and agricultural management: driving forces to improve food quality and safety?". COST 859, St. Étienne, France.

Sun X.L. and Ghosh U. (2007), PCB bioavailability control in Lumbriculus variegatus through different modes of activated carbon addition to sediments, Environmental Science and Technology, 41, 47744780.

Sun X.L. and Ghosh U. (2008), The effect of activated carbon on partitioning, desorption, and biouptake of native polychlorinated biphenyls In four freshwater sediments, Environmental Toxicology and Chemistry, 27, 2287-2295.

Tomaszewski J.E. and Luthy R.G. (2008), Field deployment of polyethylene devices to measure PCB concentrations in pore water of contaminated sediment, Environmental Science and Technology, 42, 6086-6091. 
Tomaszewski J.E., McLeod P.B. and Luthy R.G. (2008), Measuring and modeling reduction of DDT availability to the water column and mussels following activated carbon amendment of contaminated sediment, Water Research, 42, 4348-4356.

Tomaszewski J.E., Werner D. and Luthy R.G. (2007), Activated carbon amendment as a treatment for residual DDT in sediment from a superfund site in San Francisco Bay, Richmond, California, USA, Environmental Toxicology and Chemistry, 26, 2143-2150.

Vasilyeva G.K., Kreslavski V.D., Oh B.T. and Shea P.J. (2001), Potential of activated carbon to decrease 2,4,6-trinitrotoluene toxicity and accelerate soil decontamination, Environmental Toxicology and Chemistry, 20, 965-971.

Vasilyeva G.K., Strijakova E.R., Nikolaeva S.N., Lebedev A.T. and Shea P.J. (2010), Dynamics of PCB removal and detoxification in historically contaminated soils amended with activated carbon, Environmental Pollution, 158, 770-777.

Vasilyeva G.K., Strijakova E.R. and Shea P.J. (2006), Use of activated carbon for soil bioremediation, Viable Methods of Soil and Water Pollution Monitoring, Protection and Remediation, 69, 309-322.

Voparil I.M., Burgess R.M., Mayer L.M., Tien R., Cantwell M.G. and Ryba S.A. (2004), Digestive bioavailability to a deposit feeder (Arenicola marina) of polycyclic aromatic hydrocarbons associated with anthropogenic particles, Environmental Toxicology and Chemistry, 23, 2618-2626.

Werner D., Higgins C.P. and Luthy R.G. (2005), The sequestration of PCBs in Lake Hartwell sediment with activated carbon, Water Research, 39, 2105-2113.

White J.C. (2009), Optimizing planting density for p,p'-DDE phytoextraction by Cucurbita pepo, Environmental Engineering Science, 26, 369-375.

Ying G.G., Kookana R.S. and Mallavarpu M. (2005), Release behavior of triazine residues in stabilised contaminated soils, Environmental Pollution, 134, 71-77.

Yu X.Y., Ying G.G. and Kookana R.S. (2009), Reduced plant uptake of pesticides with biochar additions to soil, Chemosphere, 76, 665-671.

Zimmerman A.R. (2010), Abiotic and microbial oxidation of laboratory-produced black carbon (biochar), Environmental Science and Technology, 44, 1295-1301.

Zimmerman J.R., Bricker J.D., Jones C., Dacunto P.J., Street R.L. and Luthy R.G. (2008), The stability of marine sediments at a tidal basin in San Francisco Bay amended with activated carbon for sequestration of organic contaminants, Water Research, 42, 4133-4145.

Zimmerman J.R., Ghosh U., Millward R.N., Bridges T.S. and Luthy R.G. (2004), Addition of carbon sorbents to reduce PCB and PAH bioavailability in marine sediments: Physicochemical tests, Environmental Science and Technology, 38, 5458-5464.

Zimmerman J.R., Werner D., Ghosh U., Millward R.N., Bridges T.S. and Luthy R.G. (2005), Effects of dose and particle size on activated carbon treatment to sequester polychlorinated biphenyls and polycyclic aromatic hydrocarbons in marine sediments, Environmental Toxicology and Chemistry, 24, 15941601. 